\title{
The Ranking Urban Districts on Based Smart Growth Indexes. Case study: Zone 6 of Tehran City
}

\author{
Asghar Abdoli (Corresponding author) \\ Ph.D student of geography and urban planning, University of Isfahan, Isfahan, Iran.
}

Tel: 98-938-941-9860. E-mail: abdoli_asghar@yahoo.com

Jamal Mohammadi

Assistant professor of geography and urban planning, University of Isfahan, Isfahan, Iran

Mohammad Baghare Ghalibaf

Associate professor of geography, Tehran University, Tehran, Iran

Seyed Mousa Pour Mousavi

Assistant professor of geography, Imam Hossein University, Tehran, Iran

Received: February 12, 2014

Accepted: February 24, 2014

doi:10.5296/emsd.v3i1.5102 URL: http://dx.doi.org/10.5296/emsd.v3i1.5102

\begin{abstract}
The importance of urban form on sustainable development has been recognized in recent years. Since the late 20th century, a number of countries have adopted urban form policies in environmental planning. Urban form directly affects habitat, ecosystems, endangered species, and water quality through consumption, fragmentation, and or replacement of the natural cover with an impervious surface. The urban sprawl development has led to urban instability and many social, economic, cultural, physical and environmental problems in major cities especially Tehran. This study attempts to investigate the urban development type and how to apply smart urban growth principles for organizing and improving this growth in zone 6 of Tehran city. In fact, The purpose of this research is analysis of Hierarchy Urban districts of zone 6 Tehran on the based Urban smart growth Indexes. This study is an applied research and adopts a descriptive-analytical method. In order to assess smart growth indexes (economic, social, cultural-educational, physical and land functions, healthcare, urban facilities and equipment, environmental and accessibility) the ranking of districtsand the selection of the best section of TOPSIS model was used as the multi-index decision-making method. At last, the study investigates the correlation between the research variables and the urban smart growth integrated index by employing the regression test.
\end{abstract}




\section{MInstitute Machin $_{\text {Int }}$}

The research findings reveal that the physical and land use sections have the most influence on the spatial and physical structure of smart urban growth in zone 6 and the accessibility and the cultural-educational sections occupy the next ranks. Besides, the findings resulted from integrated indexes of smart growth indicate that district 1 with the TOPSIS grade of 0.8921 is known as the top development, and district 4 with the TOPSIS grade of 0.3292 is considered as the low development district among Tehran's 6 zone.

Keywords: Ranking, TOPSIS model, smart growth, Urban districts, zone 6 of Tehran city

\section{Introduction}

Nowadays cities spaces have become with social conflicts location, and access with many facilities, has replacement social- economical segregation to ethnic racial segregation. Therefore discussion of spatial inequalities in cities and necessary of establishment of social Justice in enjoyment of all citizens for public services have become with one serious discussion for urban planners and management. Urbanization, growth of urban population and the consequent development of small and major cities are of the characteristics of the current era. After the industrial revolution, cities attracted a major proportion of the world's population so that urban areas are estimated to have accommodated about 50 percent of the world's population in 2000. From 1990 to 2030, the urban population will increase up to 3.3 billions 90 percent of which will live in the urban areas of the developing countries (Flood, 1997). The increasing development of urban population caused by uncontrolled population growth and migration has lead to unplanned construction and uncontrollable spread of cities (Barton et al, 2003: 18).

In Iran, since the 1960s that the urban population dramatically increased both because of the quick natural growth and the immigration of villagers to cities, the physical growth and the growth of construction took place based not upon the needs of cities but rather, upon exchange game and land speculation. This issue led to disorder in urban land market and disuse of a major part of the lands inside urban boundaries as well as the negative and horizontal growth of cities. Tehran was once known as the city of plantains so that passengers often complained about the excessive density of the surrounding trees and gardens (Madanipoor, 2002: 1). Like other major cities, this city, too, has undergone fast, uncontrolled growth in recent years and due to being the capital city and experiencing substantial immigration it has undergone many population and environmental changes so that it accommodates a quarter of the country's urban population. Tehran, with a population of 2,270,000 individuals and an approximate area of 180 square kilometers in 1986 has turned into a city with a population of 7,200,000 individuals and an area of 707 square kilometers in 2001. According to the census conducted by Iran's center of statistics, Tehran's population had reached 7,872,220 individuals and 2,287,664 families (Iran's center of statistics, 2006). Therefore, a kind of unplanned and instable urbanization has happened in this city. After the Islamic revolution, Tehran experienced rapid development in different areas out of legal boundaries and this city continued its development in different areas without following rules and restrictions. Besides, the restrictions previously enforced both inside and outside the area of urban services were totally ignored .Tehran's continuous and non-continuous growth and 
its merging into areas surrounding it has made it into a collection of outspread, heterogeneous foci integrated into a network of economic and social relations (Hamidi et al, 1997: 73).

Today, despite having urban and regional development plans, this city is facing various challenges. Population growth and vast immigration into this city have created an integrated network of economic, cultural, social and environmental issues comprising the inefficiency of urban development plans, the lack of people's active participation in urban management and the lack of integrated management of this metropolis. Land and housing shortage, heavy traffic, unemployment, formation of informal settlement places in different parts of the city, high housing costs, environmental problems, air pollution and inequitable distribution of services and facilities in the city and the formation of the uptown-downtown phenomenon have led to the citizens' discontent. The sum of these factors indicates the conditions of instable development of the major city of Tehran.

In such conditions, it is essential to correct the negative consequences of the unreasonable spread. However, few solutions have been proposed to tackle the negative phenomenon of population growth. In this regard, strategies such as smart growth, smart management, green belts and land use management have been offered as solutions for the spread problem (Ghorbani and Noshad, 2008: 164).

Considering the issues and problems mentioned in Tehran, this study attempts to investigate the spatial development of the area under study based upon the principles of smart growth. In other words, the study's main focus is to investigate the role of urban smart growth in the sustainability of the area under study (zone 6 of Tehran's municipality).

\section{Theoretical Background of Research}

A review of the related literature reveals that in the two last decades, the smart growth strategy had been based upon the sustainable urban development theory and the support of the compact city model. In fact, because of the undesirable effects of the sprawl development model in political and bio-environmental areas, attention to the compact city and smart methods has increased. Proponents of this approach emphasize the compact form of the city because it enhances the efficiency of urban environment in terms of energy consumption and the reduction of travels within the city.

Smart growth policies tend to reduce per capita impervious surface area (land covered by buildings or paved for roads and parking facilities), vehicle ownership and vehicle travel, and increase use of alternative modes compared with more dispersed, automobile-dependent, sprawled communities. The can provide various savings and benefits:

- Reduced impervious surface reduces storm water management costs and heat island effects (increased ambient temperatures on sunny days), and leaves more land for other productive uses, including farming and wildlife habitat.

- More compact development reduces the capital and operating costs of providing public infrastructure and services such as roads, utility lines, garbage collection, emergency services and school transport.

- More compact development improves overall accessibility (people's ability to reached 


\section{Macrothink}

desired goods and services). This increases the efficiency of activities that involve distribution (products delivered to a destination) or interaction (people and materials brought together).

- More compact development reduces transportation costs, including the per capita costs to consumers to own and operate vehicles, road and parking facility costs, traffic accidents, and pollution emissions. (litman, 2011:1)

In fact, the smart growth strategy attempts to reform cities and direct them toward being able communities with desirable accessibility and environment. Focusing on the revitalization of cities and the development of transportation costs, smart growth aims to build places which appeal to the people. Attempting to build a community with a unique concept of place and emphasizing the minimum use of automobiles, smart growth is, in fact, looking for high understanding, interpretation and improvement of the environment. Other objectives of smart growth include: protecting urban resources and re-investment in reconstructing their structures, preserving monuments, and designing new districts so that shops, offices, schools, religious places, parks and other facilities are near houses and residents could have choices for walking, biking, access to transportation systems or driving cars.

In fact, smart growth is a tool-centered concept whose proponents agree upon its 10 principles proposed by the American environmental protection agency (EPA). These principles comprise:

- developing complex uses,

- emphasizing benefits of designing compact buildings,

- providing various choices for housing,

- Constructing districts with access to sidewalk,

- attractive neighborhoods away from one another having a high sense of identity,

- protecting open spaces, farmlands, beautiful nature and sensitive environmental areas'

- improving development in line with the present communities'

- providing a variety of transportation choices,

- predictable development decision-makings,

- encouraging communities and beneficiaries to participate in the development (www.smartgrowth.com).

Smart growth can be applied in various conditions, including rural, suburban and urban. In rural areas it means clustering more development into villages. In suburban areas it means creating complete, mixed-use, walkable neighborhoods.

Smart growth can provide various economic, social and environmental benefits, as summarized in Table 1. These benefits result from various features of smart growth, including reduced per capita land consumption, less dispersed development, and more diverse 
transportation systems. Of course, the benefits of a particular smart growth program depend on its specific features and the conditions in which it is implemented. The existence of these benefits has been demonstrated in numerous studies and is widely accepted by a diverse range of professions and interest groups, including the American Planning Association, the Institute of Transportation Engineers, the International City/County Management Association, the National Governors Association, the National Trust for Historic Preservation, and various farming and environmental organizations.

Table 1. Smart Growth Benefits

\begin{tabular}{|l|l|l|}
\hline Economic & Social & Environmental \\
\hline Infrastructure cost savings & $\begin{array}{l}\text { Improved transport options, } \\
\text { particularly for non-drivers }\end{array}$ & $\begin{array}{l}\text { Greenspace \& habitat } \\
\text { preservation }\end{array}$ \\
\hline Public service cost savings & Increased housing options & Energy savings \\
\hline Transportation efficiencies & Community cohesion & $\begin{array}{l}\text { Air pollution } \\
\text { reductions }\end{array}$ \\
\hline Economic resilience & $\begin{array}{l}\text { Cultural resource preservation } \\
\text { (historic sites, traditional } \\
\text { neighborhoods, etc.) }\end{array}$ & $\begin{array}{l}\text { Water pollution } \\
\text { reductions }\end{array}$ \\
\hline Agglomeration efficiencies & $\begin{array}{l}\text { Increased physical exercise and } \\
\text { health }\end{array}$ & $\begin{array}{l}\text { Reduced "heat } \\
\text { island" effect. }\end{array}$ \\
\hline $\begin{array}{l}\text { Supports industries that depend on } \\
\text { high quality environments (tourism, } \\
\text { farming, etc.) }\end{array}$ & & \\
\hline
\end{tabular}

(Littman, 2005: 122)

Smart growth includes more integrated transport and land use planning, so for example, most homes are within convenient walking distance of schools, shops and public transit. These features help reduce chauffeuring burdens and school busing, providing savings to households and governments.

Smart growth can also increase some costs. More compact development can increase the intensity of traffic congestion intensity, although sprawl tends to increase the distances between destinations, and therefore the per capita vehicle travel and congestion delays (Cortright 2010). Smart growth may increase some infrastructure costs, such as curbs and sidewalks, and may increase the costs per parking space, particularly if it requires structured rather than surface parking, although it tends to reduce the number of parking spaces per capita, so total parking costs per capita tend to be lower. People sometimes assume that smart growth increases housing construction costs, but detailed analysis indicates otherwise (Ford 2009; Miller 2008).

\section{Research Methodology}

Considering the research objectives, this study is a applied research and adopts a descriptive-analytical analysis method and it mostly consists of a survey done through field studies including observation, questionnaire and intervie, as well as the use of journals, 


\section{Macrothink}

Environmental Management and Sustainable Development

ISSN 2164-7682 2014, Vol. 3, No. 1

documents and the related books. The indexes investigated in this study comprise socio-economic, cultural, physical, and environmental issues as well as issues relating to accessibility and urban equipment and facilities. The statistical population comprises the 6 districts of 6 zone Tehran's municipality.

The TOPSIS model and the SPSS and EXCEL programs have been employed for data analysis. This model is based upon the idea that the selected choice must have the least distance from the ideal positive solution and the most distance from the ideal negative solution (the worst possible situation). The TOPSIS grade ranges from 0 to 1 . The closer the index is to 1, the more ideal its rank (Mo'meni, 2008: 24-29).

\section{Study area}

Having a population of 229,980 (Iran's center of statistics) and an area of 2,144 hectares, zone 6 is known as one of the most densely populated areas in Tehran. Occupying an area of 2,144 hectares, this zone constitutes 3.2 percent of the city's area. In this regard, the zone ranks 13 among Tehran's zones. This zone ranks first in terms of building density. About 35 percent of this area comprises residential area and 30 percent comprises official, commercial and educational areas, and about 30 percent is devoted to transportation systems.

Building density in this zone is 75 percent which is greater than the average density in the city. The proportion of population is $10,951.428$ people per square kilometer (public census of population and housing) which put the zone in the 12th rank. The annual growth of the population of ordinary families living in the zone in the 1986-1996 decade has been -0.5 percent and the zone have lost 12,656 people of its population. Population loss had increased in the next decade and had reached -0.75 percent. The Zone's use as a residential area has changed into a commercial one which has appealed to many immigrants. The zone comprises 6 district and 18 neighborhoods. Table 2 shows the system of district divisions of the investigated zone.

Table 2. System of district divisions of zone 6 of Tehran's municipality

\begin{tabular}{|c|c|c|c|}
\hline district name & 1385 population & Area (hectare) & GDP( the growth density of population) \\
\hline 1 & 19078 & 368 & 51.8 \\
\hline 2 & 57792 & 403 & 143.4 \\
\hline 3 & 41116 & 485 & 84.8 \\
\hline 4 & 33999 & 218 & 156 \\
\hline 5 & 36495 & 392 & 93.1 \\
\hline 6 & 44574 & 278 & 160.3 \\
\hline Total Numbers & 232583 & 2144 & 108.5 \\
\hline
\end{tabular}

Detaille plane of 6 zone Teharan, 1386

In the intended internal divisions, the mean of the districts' are is 357 hectares and the mean of the population is estimated at 39000. Among these districts, district 2 with a population of 57792 has the greatest population and district 1 with a population of 19078 has the smallest population. In terms of area, district 3 and 4 are the biggest and the smallest districts respectively. 


\section{Macrothink \\ Environmental Management and Sustainable Development \\ ISSN 2164-7682 \\ 2014, Vol. 3, No. 1}

\section{Investigation of Zone 6 Based Upon Smart Growth Indexes}

In order to rank district of zone 6 of Tehran's municipality in terms of smart urban growth indexes, the study employs the multi-index decision-making model (TOPSIS) and the entropy model to investigate the spatial structure of the 6 district of zone 6 of Tehran. Table 3 reveals the findings resulted from the prioritization of district of zone 6 of Tehran's municipality in terms of development indexes.

Table 3. Ranks and TOPSIS grades of the 6 district of zone 6 of Tehran municipality in terms of development indexes

\begin{tabular}{|c|c|c|c|c|c|c|c|c|c|c|c|c|c|c|}
\hline \multirow{2}{*}{$\begin{array}{l}\text { Indexes } \\
\text { District }\end{array}$} & \multicolumn{2}{|c|}{ Accessibility } & \multicolumn{2}{|c|}{ environmental } & \multicolumn{2}{|c|}{$\begin{array}{c}\text { urban } \\
\text { facilities and } \\
\text { equipment }\end{array}$} & \multicolumn{2}{|c|}{$\begin{array}{l}\text { physical and } \\
\text { land function }\end{array}$} & \multicolumn{2}{|c|}{ Healthcare } & \multicolumn{2}{|c|}{ cultural-educational } & \multicolumn{2}{|c|}{$\begin{array}{l}\text { Social - } \\
\text { economic }\end{array}$} \\
\hline & rank & $\begin{array}{c}\text { TOPSIS } \\
\text { value }\end{array}$ & Rank & $\begin{array}{c}\text { TOPSIS } \\
\text { value }\end{array}$ & rank & $\begin{array}{l}\text { TOPSIS } \\
\text { value }\end{array}$ & Rank & $\begin{array}{c}\text { TOPSIS } \\
\text { Value }\end{array}$ & rank & $\begin{array}{c}\text { TOPSIS } \\
\text { Value }\end{array}$ & rank & $\begin{array}{c}\text { TOPSIS } \\
\text { Value }\end{array}$ & rank & $\begin{array}{c}\text { TOPSIS } \\
\text { Value }\end{array}$ \\
\hline 1 & 1 & .6345 & 2 & .5246 & 2 & .4553 & 1 & .7645 & 5 & .3428 & 5 & .5565 & 2 & .7546 \\
\hline 2 & 3 & .4235 & 1 & .5669 & 4 & .3245 & 4 & .4126 & 6 & .3212 & 6 & .5232 & 1 & .8316 \\
\hline 3 & 4 & .3867 & 4 & .2879 & 3 & .3678 & 2 & .7435 & 4 & .4434 & 3 & .6524 & 4 & .5432 \\
\hline 4 & 5 & .3226 & 5 & .1765 & 5 & .1879 & 5 & .3212 & 3 & .5321 & 4 & .6014 & 3 & .5868 \\
\hline 5 & 6 & .1521 & 3 & .3876 & 1 & .5545 & 3 & .6326 & 1 & .7624 & 1 & .8898 & 6 & .4432 \\
\hline 6 & 2 & .5476 & 6 & .1354 & 6 & .1234 & 6 & .2154 & 2 & .6846 & 2 & .8668 & 5 & .4575 \\
\hline Average & \multicolumn{2}{|c|}{.3961} & \multicolumn{2}{|c|}{.3469} & \multicolumn{2}{|c|}{.3355} & \multicolumn{2}{|c|}{.5149} & \multicolumn{2}{|c|}{.5144} & \multicolumn{2}{|c|}{.6815} & \multicolumn{2}{|c|}{.6023} \\
\hline St.D & \multicolumn{2}{|c|}{.1667} & \multicolumn{2}{|c|}{.1633} & \multicolumn{2}{|c|}{.1473} & \multicolumn{2}{|c|}{.2105} & \multicolumn{2}{|c|}{.1646} & \multicolumn{2}{|c|}{.1583} & \multicolumn{2}{|c|}{.1589} \\
\hline C.V & \multicolumn{2}{|c|}{.4209} & \multicolumn{2}{|c|}{.4708} & \multicolumn{2}{|c|}{.4390} & \multicolumn{2}{|c|}{.4089} & \multicolumn{2}{|c|}{.320} & \multicolumn{2}{|c|}{.2322} & \multicolumn{2}{|c|}{.2639} \\
\hline
\end{tabular}

Source: Author's calculations

Investigations reveal that in terms of socio-economic indexes, district 2 with the TOPSIS grade of 0.8316 and district 1 with the TOPSIS grade of 0.7546 occupy the first and the second ranks respectively. In terms of cultural-educational indexes, district 5 with the TOPSIS grade of 0.8898 and district 6 with the TOPSIS grade of 0.8658 occupy the first and the second ranks respectively. This might be due to the location of Tehran, Tarbiat Modarres, arts, Amir Kabir and IRIB universities as well as the Nuclear Energy Research Center, House of Artists, Alborz high school and a large number of educational and art centers such as cinema theatres in these districts of zone 6 . In fact one of the richest urban areas of Tehran in terms of enjoying cultural-educational indexes is zone 6 of Tehran's municipality and district 1 and district 2 of this zone respectively rank first and second in terms of enjoying these indexes. In terms of health-treatment indexes, district 5 with the TOPSIS grade of 0.7624 and district 6 with the TOPSIS grade of 0.6846 occupy the firs and the second ranks respectively. That is because of the location of Imam Khomeini, Shari'ati, Asia, Firouzgar and other hospitals as well as Tehran clinic in these districts. District 2 with the TOPSIS grade of 0.3212 occupies the last rank in terms of enjoying health-treatment indexes.

In terms of physical and land use indexes, district 1 and district 3 with the respective TOPSIS grades of 0.7645 and 0.7435 rank first and second respectively. That is because of empty spaces, landscapes, public uses, and various services in these districts. Other reasons include the great extent of these districts and the low population density as well as the highest income per capita. In addition, district 6 with the TOPSIS grade of 0.2154 occupies the last rank. In 


\section{1) Macrothink}

Environmental Management and Sustainable Development

ISSN 2164-7682 2014, Vol. 3, No. 1

terms of urban equipment and facilities indexes, districts 5 and 1 with the respective TOPSIS grades of 0.5145 and 0.4553 occupy the first and the second ranks respectively in enjoying these indexes. In terms of environmental indexes, district 2 with the TOPSIS grade of 0.5698 and district 1 with the TOPSIS grade of 0.5246 occupy the first and the second ranks respectively. The reasons are considered to be closeness to recreational centers, parks, landscapes, etc. Besides, among the 6 districts of zone 6 of Tehran's municipality, districts 4 and 6 with the respective TOPSIS grades of 0.1354 and 0.1765 rank 5 and 6 respectively in terms of enjoying environmental indexes. Proximity to the central part of the city, existence of heavily-trafficked and polluted routes, insufficient landscapes, etc. are the reasons of this issue. In terms of accessibility indexes, districts 1 and 6 with the respective TOPSIS grades of 0.6345 and 0.5476 occupy the first and the second ranks respectively. This indicates the existence of balance in accessibility of various urban services in these districts.

Table 4. Ranking of the 6 districts of zone 6 of Tehran's municipality in terms of synthetic development indexes by means of TOPSIS model

\begin{tabular}{|r|r|r|r|}
\hline Indexes & Spatial development value & \multicolumn{2}{|c|}{ urban smart growth integrated index } \\
\hline District name & - & Final rank & TOPSIS value \\
\hline 1 & top development & 1 & .8921 \\
\hline 2 & top development & 3 & .6498 \\
\hline 3 & Developed & 4 & .5218 \\
\hline 4 & low development & 6 & .3292 \\
\hline 5 & top development & 2 & .7358 \\
\hline 6 & Semi developed & 5 & .4156 \\
\hline Average & - & & .5907 \\
\hline St.D & - & & .1911 \\
\hline C.V & - & & .3235 \\
\hline
\end{tabular}

Source: Author's calculations

In synthetic indexes, the mean of the TOPSIS grade of the districts of zone 6 of Tehran municipality is 0.5907 and the standard deviation of these indexes is 0.1911(Table 4). According to the calculations, the sprawl coefficient of this index is estimated at 0.3235 percent which indicates difference and dispersal in enjoying indexes among the districts of zone 6 of Tehran. Of course this difference and dispersal is not great and somewhat indicates the smartness of this zone. In general, district 1 with TOPSIS grade 0.8921 occupies the first rank (highly-developed), district 5 with TOPSIS grade 0.7358 the second rank (highly-developed), district 2 with TOPSIS grade 0.6498 the third rank (highly-developed), district 3 with TOPSIS grade 0.5218 the fourth rank (highly-developed), district 6 with TOPSIS grade 0.4156 the fifth rank (semi-developed), and district 4 with TOPSIS grade 0.3292 occupies the sixth rank (underdeveloped).Because of being located in the city center, high population density, old and dilapidated buildings, high traffic volume, lack of regular and timely access to services, etc. district 6 enjoys low smart growth indexes in comparison with other districts. 


\section{$\triangle$ Macrothink}

The study employs regression analysis in order to predict indexes influential in smart urban growth. The findings of the regression analysis generally indicate that among the 7 indexes (socio-economic, cultural-educational, health-treatment, physical-land use, facility-equipment, accessibility, and environmental), the physical-land use, accessibility and educational-cultural indexes have the greatest impact on the development of the spatial-physical structure of smart urban growth of the 6 districts of zone 6 of Tehran (table 5).

Table 5. Statistics of the coefficients of the regression model of smart urban growth indexes

\begin{tabular}{|l|l|l|l|}
\hline Indexes & & $\mathrm{T}$ & $\mathrm{Sig}$ \\
\hline Social-economic & -.054 & -.276 & .565 \\
\hline cultural-educational & .21 & 1.722 & 000 \\
\hline Healthcare & .084 & .414 & .284 \\
\hline physical and land function & .732 & 6.652 & 000 \\
\hline urban facilities and equipment & .003 & .142 & .122 \\
\hline Environmental & .652 & 5.463 & 000 \\
\hline Accessibility & .063 & .246 & .242 \\
\hline
\end{tabular}

Source: Author's calculations

As shown by table 5, one unit of change in the physical and land use, accessibility and cultural - educational sections respectively causes $0.732,0.652$, and 0.212 units of change in the synthetic indexes of smart urban growth. This indicates that the physical and the land use sections have the greatest impacts on the synthetic indexes of smart urban growth. Other sections have small and in some cases reducing effects so that the socio-cultural indexes have had negative impacts on the dependant variable of the research (synthetic indexes of smart urbangrowth).

\section{Conclusions and Suggestions}

Smart growth is: planning, designing, developing and renovating, promoting location sense, preserving natural and cultural resources and delivering development advantages and disadvantages fairly (SGN, 2002). Smart growth network accepts following ten principles as principles of urban smart growth: 1) Mix land uses; 2)Take advantage of compact building design; 3)Create a range of housing opportunities and choices; 4)Create walk able neighborhoods; 5)Foster distinctive, attractive communities with a strong sense of place; 6)Preserve open space, farmland, natural beauty, and critical environmental areas; 7)Strengthen and direct development towards existing communities; 8)Provide a variety of transportation choices (Ghorbani \& Noshad, 2008); 9)Make development decisions predictable, fair and cost effective; 10)Encourage community and stakeholder collaboration in development decisions

The findings resulting from the ranking of districts indicates inequality and difference in some indexes. The greatest inequality is seen in cultural-educational indexes and the smallest inequality is seen in the environmental indexes. According to the synthetic results of the smart urban growth, district 1 with TOPSIS grade 0.8921 occupies the first rank and district 4 with TOPSIS grade 0.3292 occupies the last rank. These two districts are considered the 


\section{Ml Macrothink}

Environmental Management and Sustainable Development

ISSN 2164-7682

2014, Vol. 3, No. 1

highly-developed and the under developed districts among zone 6 districts. Considering the inequality in the smart growth indexes of the zone, district 4 which is deemed the underdeveloped district must be the first priority for development planning. In the socio-economic index, district 2 occupies the first and district 5 the last ranks. In the cultural-educational index, district 5 ranks first and district 2 ranks last. In the health-treatment index, district 5 occupies the first and district 2 the last ranks. In the physical and land use index, district 1 ranks first and district 6 ranks last. In the urban equipment and facilities index, district 5 occupies the first and district 6 the last rank. In the environmental index, district 2 ranks first and district 6 ranks last. Finally, in the accessibility indexes district 1 occupies the first and district 5 occupies the last ranks.

Of the above-mentioned indexes, the physical and land use section exerts the greatest influence on the spatial structure of the smart growth of zone 6. The obtained coefficient ' $t$ ' (6.652) indicates a significant correlation between the two above variables so that there is 0.732 unit of change in the synthetic indexes of smart growth per one unit of change in the physical and land use section.

The most efficient strategy for moving urban development toward sustainability is the smart urban growth strategy which requires designing and planning land use based upon walking accessibility as well as adding to the services in the whole of the city. In order to achieve such growth, some suggestions have been offered such as providing all citizens with spatial equitability in accessing urban services, encouraging residence by constructing complexes and small residential units, reducing the use of private transportation vehicles, using integrated and smart urban management, using the compact city model in urban constructions, managing parking lots proficiently, improving the design of the zones' street, involving citizens in urban development decision-makings, valuing nature, developing a culture which uses less pollutants in order to have a cleaner city, developing eight approved subway lines in the zone, planning to reduce building density and the gross density of population in the zone, and finally, improving public transportation considering the location of three main highways of Tehran near the intended zone.

The with attention that access of areas with urban services is not equal, and areas population low in compared with areas population full have access more services, that this show high negative correlation between population and services distribution in between areas is. Therefore in field of public services distribution in Tehran city not observe access justice. So attention with this problem for solution of Tehran city problems and providing of fields urban sustainable development in this city is necessary.

\section{References}

Barton, H., et al. (2003). Shaping neighborhoods: Agued for health, sustainability and vitally, sponpress, London and New York.

Flood, J. (1997). Urban and housing indicator. Urban Studies, 34(10), 1635-1665. http://dx.doi.org/10.1080/0042098975385 


\section{Macrothink}

Environmental Management and Sustainable Development

ISSN 2164-7682

Ghorbani, R., \& Noshad, S. (2008). Smart Urban Growth Strategy in Urban Development: Aspects and Strategies, Journal of geography and development, Sistan and Balochestan University Press, 12, 163-180.

Hamidi, M., SirousSabri, R., \& Hababi, M. (1997). Tehran's skeleton. 1st Vol., Tehran: Tehran municipality.

Iran's Center of statistics, results of the public census of population and housing of the years 2006-2011.

Jason, M. (2008). Production-Built Homes: The Cost Advantages of Smart Growth, U.S. Environmental Protection Agency at: www.epa.gov/smartgrowth/sg_business.htm.

Joe, C. (2010). Driven Apart: How Sprawl is Lengthening Our Commutes and Why Misleading Mobility Measures are Making Things Worse, CEOs for Cities.(www.ceosforcities.org); at www.ceosforcities.org/work/driven-apart.

Jonathan, F. (2009). Smart Growth \& Conventional Suburban Development: Which Costs More? U.S. Environmental Protection Agency (www.epa.gov/smartgrowth/sg_business.htm); at: www.morrisbeacon.com/images/documents/MBD\%20EPA\%20infrastructure.pdf.

Littman, T. (2005). Evaluating Criticism of smart growth, Victoria Transport Policy Institute.

Littman, T. (2011). Understanding smart growth saving, Victoria transport policy institute.

Madanipoor, A. (2002). Tehran, Emergence of a Metropolis. Translated by Zararound, H., Tehran: urban planning and process publication.

Mo'meni, M. (2008). A View of the Theoretical Foundations of the Current Geography by Emphasizing Urban Geography. Classroom pamphlet, department of geography, faculty of geology, Tehran: Shahid Beheshti University.

Smart Growth Network (SGN). (2002). About smart growth. http://www. smartgrowth.org/about.

The detailed plan of zone 6 of Tehran's municipality.

VTPI. (2006). Online TDM Encyclopedia, Victoria transportation policy Institute.

\section{Copyright Disclaimer}

Copyright reserved by the author(s).

This article is an open-access article distributed under the terms and conditions of the Creative Commons Attribution license (http://creativecommons.org/licenses/by/3.0/). 